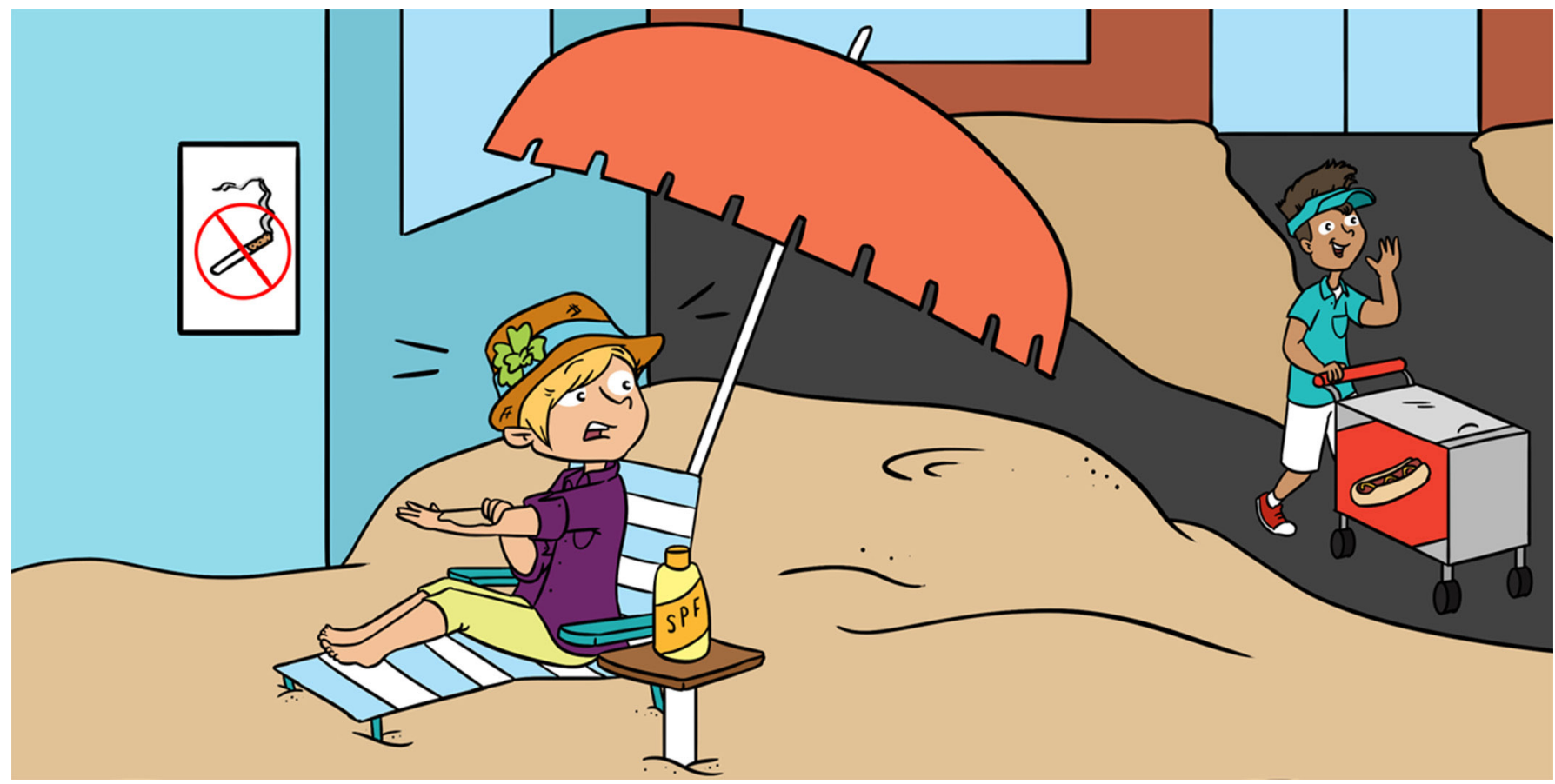

\title{
WAYS YOU CAN PROTECT YOUR GENES FROM MUTATIONS WITH A HEALTHY LIFESTYLE
}

\section{Claire L. Slote ${ }^{1}$, Ashley Luu ${ }^{2}$, Niranjana Mariya George ${ }^{2}$ and Nicole Osier ${ }^{1,3 *}$}

\section{School of Nursing, The University of Texas at Austin, Austin, TX, United States}

College of Natural Sciences, The University of Texas at Austin, Austin, TX, United States

'Dell Medical School, The University of Texas at Austin, Austin, TX, United States

\section{YOUNG REVIEWERS:}

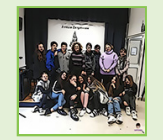

CLASSE IIICISTITUTO

COM-

PRENSIVO

CAMPODEL MORICINO

AGES: $12-15$
DNA is the recipe for all life on Earth, by coding for proteins that the entire organism is made of. Our bodies have complex systems in place that make sure our DNA is organized properly and that each new cell gets a complete and unchanged copy. If the complex system involved in copying DNA fails, or if bad things are present in the environment, a mistake in the sequence of DNA can occur. These mistakes, called mutations, can happen at any phase of life, beginning with a growing baby's first cells all the way to an adult's mature cells. Some mutations cause serious health problems. The purpose of this article is to highlight the many harmful villains, called mutagens that cause mutations, and how we can protect our bodies from harm by maintaining a healthy lifestyle and avoiding unnecessary exposure to the types of hazards that can cause mutations. 
DEOXYRIBONUCLEIC

\section{ACID (DNA)}

The molecular "recipe" that contains the instructions for an organism. DNA is made of four bases held together by a sugarphosphate background DNA is present in all living organisms and is responsible for helping pass on genes when cells divide.

\section{Figure 1}

Drawing of the way two strands of DNA pair together to form the double helix structure. The chemical structures of the bases are shown on the right, and they are color coded so that you can see, in the double helix that $A$ pairs with $T$ and $C$ pairs with $G$. The sugar-phosphate backbone is shown as a gray strip holding the bases together. Remixed and Adapted from DNA RNA by Dr. Osier in Canva. File: Difference DNA RNA-DE.svg: Sponk/*translation: Sponk [CC BY-SA 3.0 (https:// creativecommons.org/ licenses/by-sa/3.0), GFDL (http://www.gnu org/copyleft/fdl.html)], via Wikimedia Commons.

\section{WHAT IS DNA?}

Without DNA, you would literally not exist! Neither would your pet, the trees in your yard, nor the meat, fruits, and vegetables you had for lunch. Anything that is or was alive can thank DNA! DNA is essentially a recipe that allows an organism to produce the basic materials (proteins) that make up each cell. Cells work together as tissues, organs, and organ systems to form an entire organism. DNA is made of four different molecules called bases: adenine (A), guanine (G), cytosine (C), and thymine $(T)$. These four bases are strung together into a long chain. The backbone linking the bases is referred to as the "sugar-phosphate backbone," because it is made up of alternating sugar and phosphate molecules. The order of the bases is referred to as the DNA sequence. Each set of three bases in the DNA sequence is referred to as a codon. Most codons code for one of the 20 amino acids that make up proteins. When the codon does not correspond to an amino acid, it is referred to as a stop codon, because it tells the cell that the end of the recipe has been reached and that production of the protein is done. DNA normally exists as two strands that wind into a shape called a double helix, with the bases on the two strands paired in a predictable way: A always pairs with $T$, and $G$ with $C$ (see Figure 1). To further enhance your understanding of the structure of DNA, we recommend the sweet (pun intended) depiction of the double helix made out of gummy bears and licorice, in

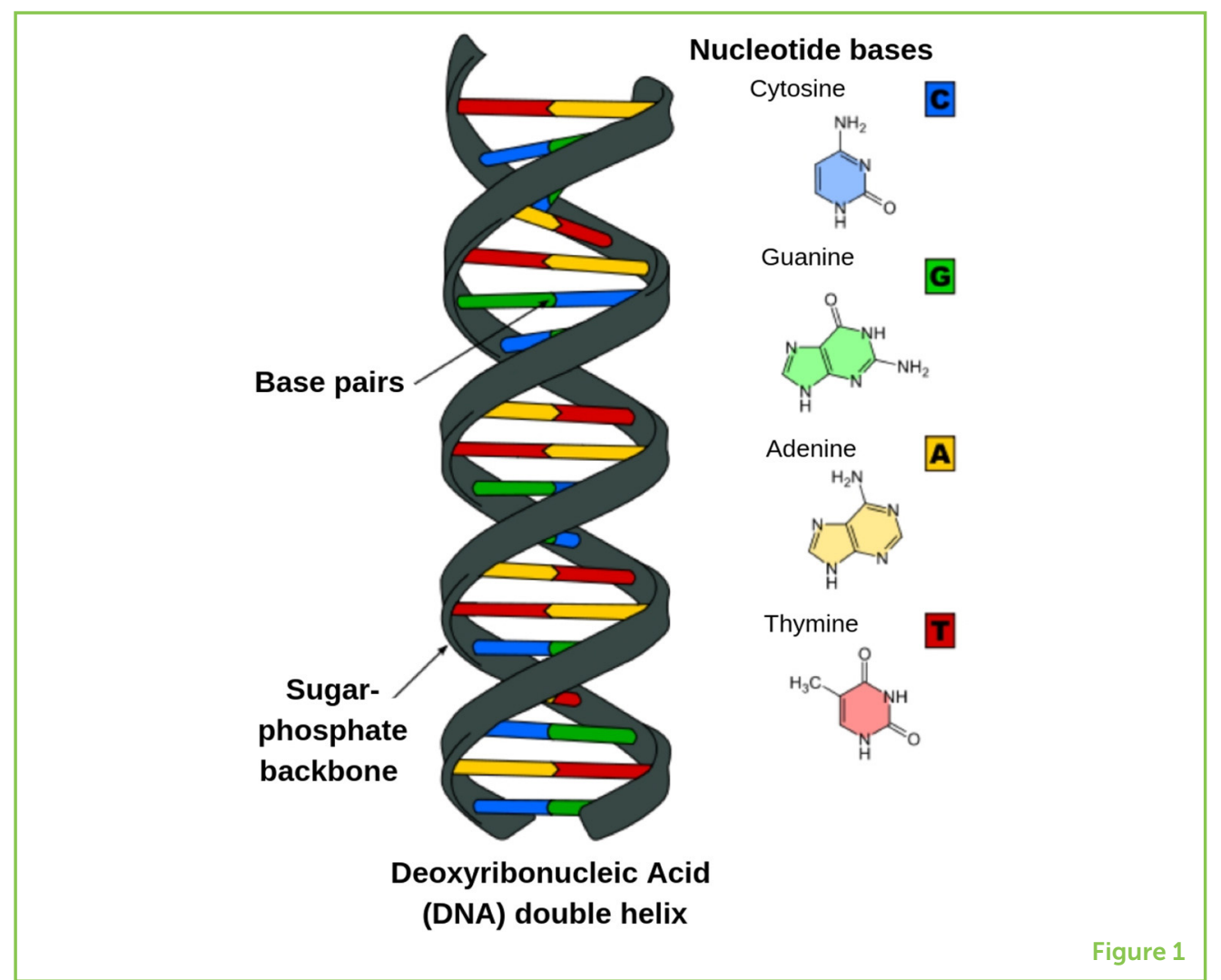




\section{CODON}

A set of three bases in DNA that codes for one amino acid.

\section{MUTATIONS}

Changes in an organism's DNA sequence that may or may not alter proteins.

Figure 2

Examples of common types of mutations. (A) The "normal" DNA sequence without a mutation, (B) an insertion, where a base is added, (C) a deletion, where a base is removed, (D) a duplication, where some bases are repeated, and (E) an inversion, where the order of bases is reversed. the 2018 Frontiers for Young Minds article about the genetics of heart disease by Clark, Alibhai, and Rutland [1]!

So, how many of these bases are there? Well, human DNA contains $\sim 3$ billion bases and about $99 \%$ of these bases are the same in all humans [2]. The $1 \%$ difference contributes to all of the unique traits and characteristics, such as eye color or health status, that vary between you and other people. The ways you are different from your classmates, friends, and siblings is due to your DNA sequences being different from theirs. About half of your DNA comes from each of your parents. More than $1 \%$ difference in DNA means that an organism is a different species than us. Chimpanzee DNA is between 1 and 2\% different from human DNA (meaning that chimpanzees DNA is $98-99 \%$ identical to human DNA), making them our closest relatives in the animal kingdom [3].

\section{WHAT IS A MUTATION?}

Now that we understand some basics about DNA, we can talk about how the sequence can change. Sometimes our DNA sequence gets altered; this is called a mutation. There are different types of mutations. For example, a base can be changed from what it was originally supposed to be to a different base (substitution), a base or bases can be deleted from the DNA (deletion), a base or bases can be added to the DNA (insertion), or a piece of DNA can be flipped (inversion) or repeated (duplication) (see Figure 2).

While mutations always change the DNA sequence, they do not always cause a change in the resulting protein or an obvious effect on the organism. This can occur because most amino acids can be coded by two or more different codons. For example, the DNA sequence CAA codes for the amino acid valine, but so does the sequence CAG. So, if a

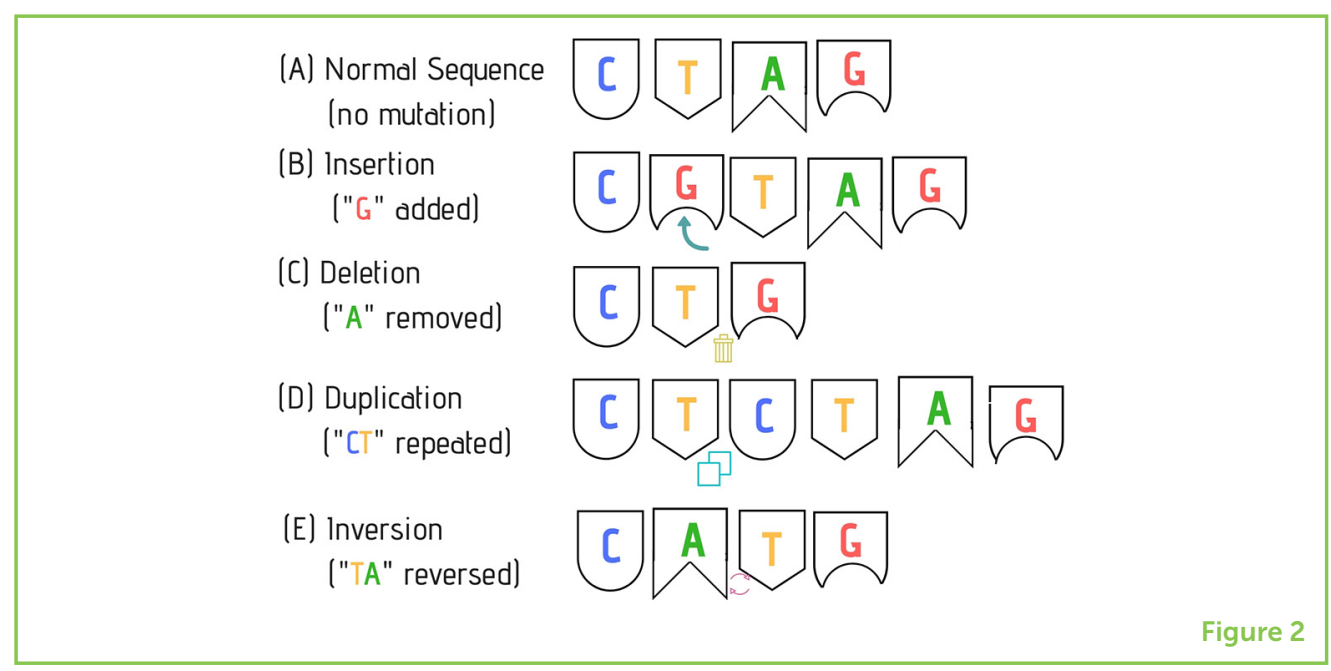


substitution mutation changes the DNA sequence from CAA to CAG, a valine would still be added to the protein. Mutations that do not affect the protein are called silent mutations, because the DNA still makes the same protein that would be expected, and a person with a silent mutation would not even realize it. Other times, the change in the DNA sequence does affect the protein. This can happen, for example, if the DNA sequence CTC is changed to CAC. In this case, the amino acid glutamic acid would be replaced with valine. This specific sequence change is the mutation found in most people with sickle cell anemia, which is a very painful condition. Other times, a base is inserted into or deleted in the DNA sequence, which alters the way codons are read. This results in a large number of amino acids being altered, which is called a frameshift mutation. For example, if the original sequence AAA-CCC-GGG has a T added after the first A, it would now be read as ATA-ACC-CGG-G...; this would change the amino acid sequence from phenylalanine-glycine-proline to tyrosine-tryptophan-alanine. Notice how none of the amino acids in the protein made from the mutated DNA are the same as the original sequence. This would likely have a big impact on the protein's function! A third possibility is that the mutated DNA sequence causes the protein production to stop early, so that the protein is shorter than normal. This is referred to as a nonsense mutation. If the DNA sequence AAA-ACC-AAA-AAA were changed to AAA-ACT-AAA-AAA, the protein sequence would change from phenylalanine-tryptophan-phenylalanine-phenylalanine to a single phenylalanine only, because the sequence ACT would act as a stop codon. So, the resulting protein would be shorter than normal and would not function properly.

INHERITED

MUTATIONS

A mutation that is passed down from the mother or the father.

\section{ACQUIRED}

\section{MUTATIONS}

A mutation that is caused by environmental factors and does not affect cells passed down to future offspring.
Mutations can be passed down from the mother or father to the developing baby, and these are called inherited mutations. For example, if your mother had a mutation that caused her to be a lot shorter than average, you could inherit her mutation and be shorter than average yourself. You might tell your friends that you got your short stature from your mom, or that being short runs on your mom's side of the family. If a person with an inherited mutation has a baby one day, that person would pass the mutation on to the next generation. With the example above, if you gave your son or daughter the short stature mutation your mom gave you, your child could say he is short because of both you and his grandmother (your mother).

Other mutations happen after birth, and these are called acquired mutations. Acquired mutations are usually due to something in the environment and their effects are usually only present in the cells that were exposed to that environmental trigger. So, some cells will have the mutation and other cells will have the normal sequence. For example, if you somehow got a mutation in the skin cells on your knee and then 


\section{THYMINE DIMERS}

A mutation that occurs on a single strand of DNA, when two thymines become connected to one another, instead of to adenines on the second strand of DNA.

\section{Figure 3}

The ultraviolet (UV) rays in sunlight cause the formation of thymine dimer mutations, which is when two thymines on the same strand of DNA bond together instead of correctly bonding with adenines on the opposite strand. This can cause mutations when making a copy of DNA for the next generation of cells. scraped your knee and had to make new cells to replace the ones that got hurt, those new cells would contain the mutation. However, the mutation would not be passed on to your future offspring, if you had a baby later.

\section{WHAT ARE SOURCES OF MUTATIONS AND HOW CAN I PREVENT THEM?}

\section{Sunlight}

Sunlight is one thing that can cause mutations. How does sunlight affect our DNA? Sunlight creates structures called thymine dimers, which means that two thymine $(T)$ bases $(T)$ on the same DNA strand become connected in an abnormal way, instead of correctly attaching to the complementary base adenine (A) on the opposite strand. Thymine dimers create kinks in the DNA shape (see Figure 3) [2]. These kinks make DNA difficult to copy, which can cause a mutation. In order to avoid thymine dimers from developing in our cells, it is very important to use sunscreen to help block ultraviolet $A$ and B (UVA and UVB) rays. The United States Food and Drug Agency (FDA) recommends a sun protection factor (SPF) of at least 15, to protect against skin cancer and early skin aging (see Table 1). Sunscreen should be reapplied every $2 \mathrm{~h}$ or after swimming, sweating, bathing, or using a towel [4]. Some individuals who have especially sensitive or light skin should consider higher levels of UV protection and are encouraged to consult a doctor called a dermatologist, who is an expert on keeping skin healthy.

\section{X-ray Radiation}

$\mathrm{X}$-ray radiation is the kind used in X-rays (medical images) taken of teeth, bones, and other hard body parts. X-ray radiation has a very high energy level that can create molecules called free radicals.

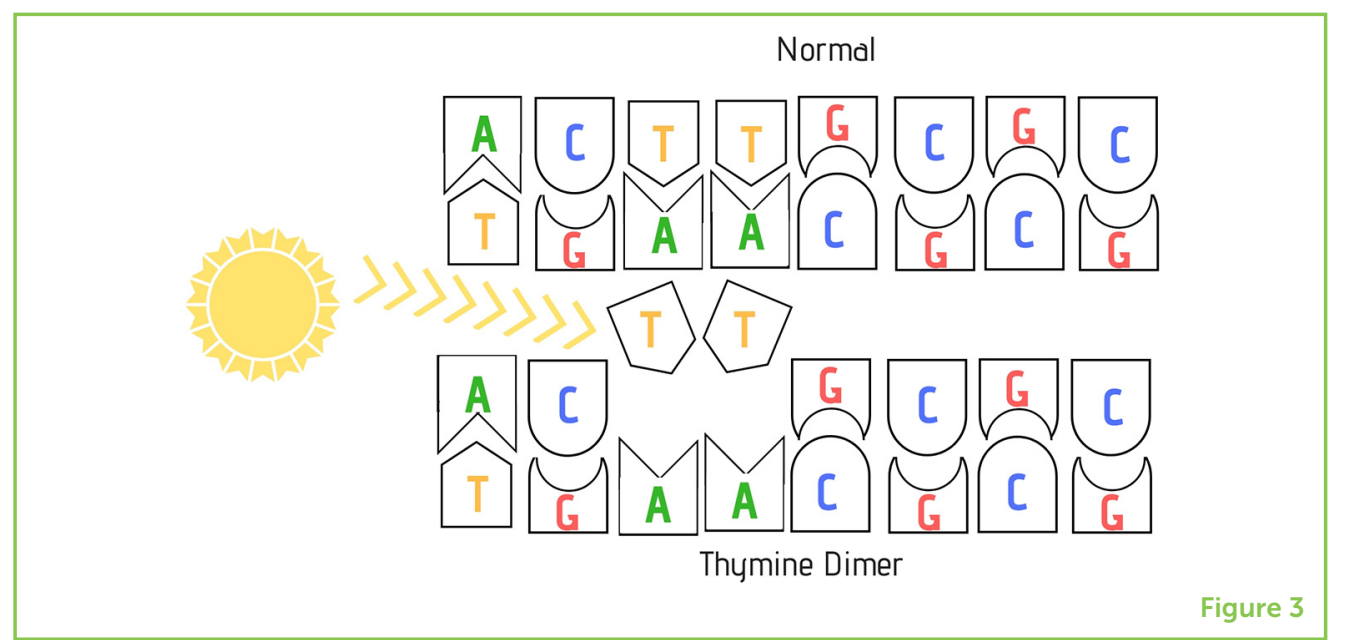


Table 1

Environmental factors that can cause mutations.

\section{CARCINOGENS}

Substances/chemicals that can cause mutations that can result in cancer.

\begin{tabular}{|c|c|c|}
\hline Mutagen & Risk factors & $\begin{array}{l}\text { Health behavior that prevents } \\
\text { exposure }\end{array}$ \\
\hline Sunlight & $\begin{array}{l}\text { Increased exposure to sunlight } \\
\text { leading to thymine dimers in } \\
\text { DNA }\end{array}$ & $\begin{array}{l}\text { - Wear sunscreen } \\
\text { - Avoid excess sun exposure } \\
\text { - Reapply sunscreen every } 2 \mathrm{~h} \\
\text { - Wear clothes/hat that cover } \\
\text { skin }\end{array}$ \\
\hline $\mathrm{X}$-ray radiation & $\begin{array}{l}\text { - Multiple X-rays } \\
\text { - Close proximity to X-rays }\end{array}$ & $\begin{array}{l}\text { - Limit the number of X-rays to } \\
\text { only ones that are necessary } \\
\text { - Wear protective lead vest over } \\
\text { areas not being X-rayed } \\
\text { - Use alternative imaging } \\
\text { devices }\end{array}$ \\
\hline $\begin{array}{l}\text { Tobacco } \\
\text { products }\end{array}$ & $\begin{array}{l}\text { - Smoking } \\
\text { - Chewing tobacco } \\
\text { - Second-hand smoke }\end{array}$ & $\begin{array}{l}\text { - Avoid smoking/tobacco } \\
\text { products } \\
\text { - Avoid being near smoke }\end{array}$ \\
\hline Chemicals & $\begin{array}{l}\text { Increased exposure to } \\
\text { carcinogenic/mutagenic } \\
\text { chemicals }\end{array}$ & $\begin{array}{l}\text { - Limit exposure } \\
\text { - Dispose of chemicals properly } \\
\text { - Wear protective gear }\end{array}$ \\
\hline Nitrites & $\begin{array}{l}\text { Increased consumption of pro- } \\
\text { cessed meats, such as hot dogs, } \\
\text { sausages, and bacon }\end{array}$ & $\begin{array}{l}\text { Limit consumption of processed } \\
\text { meats and grilled meats }\end{array}$ \\
\hline
\end{tabular}

Table 1

Free radicals are very unstable, and to become more stable, they can steal electrons from DNA, which can lead to mutations [5]. We can reduce exposure to $\mathrm{X}$-ray radiation by using other forms of medical images when possible and wearing protective equipment to protect the body when x-rays are taken. If you have ever gone to the dentist and had an X-ray of your teeth, you probably remember having a heavy lead apron draped over your body. The lead apron protects the parts of the body that the dentist is not taking pictures of. Getting X-rays only when necessary is a good practice to prevent any excessive negative effects on your DNA (see Table 1) [5]. This is why X-rays are not taken if a doctor is fairly sure a patient has sprained, not broken, an ankle.

\section{CIGARETTES AND OTHER TOBACCO PRODUCTS}

How does smoking lead to cancer? Cigarettes and tobacco products contain chemicals referred to as carcinogens, which are mutagens that are also known to cause cancer. All cancer cells have DNA mutations, and it is the carcinogens that cause the mutations. Carcinogens cause mutations by damaging the way the cell repairs DNA or makes proteins. If the cancer cell is not able to repair this DNA damage, then it will keep dividing to make new cells and will pass the mutation on to 
MUTAGENS

Substances/chemicals that cause changes in an organism's DNA sequence. all the new cells that are made. Because cancer cells grow and divide faster than normal cells, masses of these abnormal cells, called tumors, can form. The best way to avoid these carcinogens is not to smoke or use tobacco products (see Table 1). It is also important to try to limit second-hand smoke exposure, which means avoiding other people who are smoking cigarettes [6].

\section{Chemicals}

Chemical mutagens are chemicals that have been shown to cause mutations. Some chemicals are also carcinogens and can cause cancer in humans, like the ones in cigarette smoke discussed above [2]. Some other examples of chemical mutagens include benzene (a major component of gasoline), vinyl chloride (common in pipes), and arsenic (used in some insecticides and rat poison). Some chemical mutagens have not been linked to cancer. If they are not 100\% known to cause cancer, these chemicals are just referred to as mutagens, not carcinogens. To avoid mutations, we need to limit exposure to these chemicals by using protective equipment, like masks and gloves, when working with them. Once these chemicals are no longer being used, they should be properly disposed of (see Table 1).

\section{Nitrites}

Substances called nitrites are present in many processed meats, such as bacon, pastrami, salami, hot dogs, and sausages. Nitrites combine with the proteins in the meat to form other compounds, which are known to be carcinogens [7]. Now I know what you are thinking: do I have to give up my favorite foods altogether? Fortunately, the answer is no. You can still eat processed meats but eating them every day is probably not the best idea. To protect yourself from nitrites, you should limit your consumption of processed meats and also try to include healthy choices in your diet, like fruits, vegetables, and whole grains (see Table 1).

\section{CONCLUSION}

Now that you know what mutations are and how acquired mutations happen, you can take the necessary steps to help prevent yourself from getting mutations, and you can teach your friends and family about the steps they can take in their daily lives to avoid mutagens. There are more causes of mutations than we have described here, and many of them are beyond our control. That is why it is really important to prevent as many mutations as we can, so that we limit the negative effects of mutations on our health. Your DNA is such a critical molecule, it is worth protecting it however you can! 


\section{REFERENCES}

1. Clark, N., Alibhai, A., and Rutland, C. S. 2018. Mending a broken heart-the genetics of heart disease. Front. Young Minds 6:19. doi: 10.3389/frym.2018.00019

2. Ackerman, S., and Horton, W. 2018. Chapter 2.4-effects of environmental factors on DNA: damage and mutations. Green Chem. 1:109-28. doi: 10.1016/ B978-0-12-809270-5.00005-4

3. Ebersberger, I., Metzler, D., Schwarz, C., and Pääbo, S. 2002. Genomewide comparison of DNA sequences between humans and chimpanzees. Am. J. Hum. Genet. 70:1490-7. doi: 10.1086/340787

4. Latha, M. S., Martis, J., Shobha, V., Shinde, R. S., Bangera, S., Krishnankutty, B., et al. 2013. Sunscreening agents. J. Clin. Aesthet. Dermatol. 6:16-26.

5. ACHRE. 1994. Advisory Committee on Human Radiation Experiments Report. Retrieved from: https://bioethicsarchive.georgetown.edu/achre/final/summary. html\#publication

6. Centers for Disease Control and Prevention (US), National Center for Chronic Disease Prevention and Health Promotion (US), and Office on Smoking and Health (US). 2010. How Tobacco Smoke Causes Disease: The Biology and Behavioral Basis for Smoking-Attributable Disease: A Report of the Surgeon General. Atlanta, GA: Centers for Disease Control and Prevention (US). Retrieved from: https://www.ncbi.nlm.nih.gov/books/NBK53010/

7. Baena Ruiz, R., and Salinas Hernández, P. 2014. Diet and cancer: risk factors and epidemiological evidence. Maturitas 77:202-8. doi: 10.1016/j. maturitas.2013.11.010

SUBMITTED: 24 August 2018; ACCEPTED: 26 February 2019; PUBLISHED ONLINE: 19 March 2019

EDITED BY: Valeria Costantino, University of Naples Federico II, Italy

CITATION: Slote CL, Luu A, George NM and Osier N (2019) Ways You Can Protect Your Genes From Mutations With a Healthy Lifestyle. Front. Young Minds 7:46. doi: 10.3389/frym.2019.00046

CONFLICT OF INTEREST STATEMENT: The authors declare that the research was conducted in the absence of any commercial or financial relationships that could be construed as a potential conflict of interest.

COPYRIGHT () 2019 Slote, Luu, George and Osier. This is an open-access article distributed under the terms of the Creative Commons Attribution License (CC BY). The use, distribution or reproduction in other forums is permitted, provided the original author(s) and the copyright owner(s) are credited and that the original publication in this journal is cited, in accordance with accepted academic practice. No use, distribution or reproduction is permitted which does not comply with these terms. 


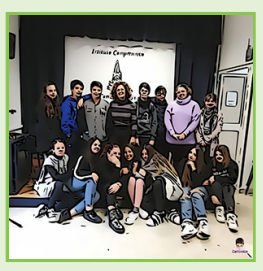

\section{YOUNG REVIEWERS}

\section{CLASSE IIIC-ISTITUTO COMPRENSIVO CAMPO DEL MORICINO, AGES: 12-15}

We are a class of 20 students who are part of the Comprehensive Institute "Campo del Moricino" which is located in an area where in the Norman-Swabian era the poor wanderers often "Mori" found burial. That is why we call ourselves that. But even if the name refers to a fatal event we are very lively, nice and united among. This project has given us the opportunity to get involved and to deepen topics studied so far only at school level we are very happy to have participated in the creation of this article, with the help of the Science teacher Lina Medugno and the English teacher Emilia Corrado. We hope to be successful and that the work can be read and easily understood by many guys like us.

\section{AUTHORS}

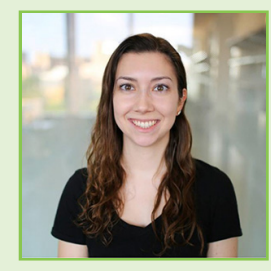

\section{CLAIRE L. SLOTE}

I am currently a registered nurse working in an intensive care unit (ICU) in Austin, TX. I recently graduated with my Bachelor's Degree from The University of Texas at Austin this past December 2018, and I started working as a nurse in February 2019. In my free time, I enjoy going to the gym, exploring new restaurants in Austin, and volunteering as a patient for the clinical simulations in UT's School of Nursing.

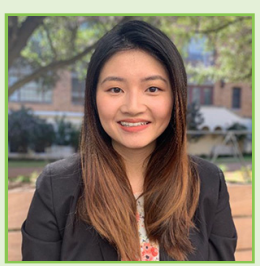

\section{ASHLEY LUU}

I am an undergraduate at The University of Texas at Austin, pursing a Bachelor of Science and Arts in Biology and a certificate in Business Foundations and another certificate in Social Inequality, Health, and Policy. After I graduate, I plan to pursue medical school, in addition to studying public health. In my free time, I love cooking, hiking, traveling, and being outdoors!

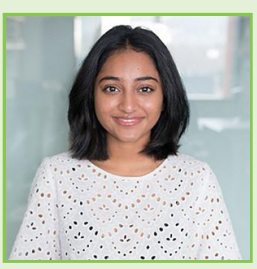

\section{NIRANJANA MARIYA GEORGE}

I am currently an undergraduate student at The University of Texas at Austin, pursing a Bachelor of Science and Arts in Neuroscience with a certificate in Business of Healthcare. I plan to attend medical school and earn a Master of Business Administration. In my free time, I like doing yoga, trying new food, and exploring Austin.

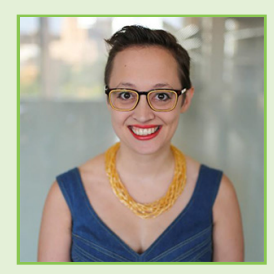

\section{NICOLE OSIER}

I am a Principal Investigator at The University of Texas at Austin. I have a Bachelor's Degree in Nutritional Science and Nursing from Michigan State University and a Ph.D. from the University of Pittsburgh. My goal is to understand what makes some individuals recover better than others after head injury and apply this information to help doctors and nurses treat it. To learn more about my laboratory, visit my website: https://nicoleosier.wixsite.com/osierlaboratory/. In my free time I enjoy spending time with my spouse and cats, and traveling the world. *nicoleosier@utexas.edu 